Pltp:/www.journals.zu.edu.eg/journalDisplay.aspx?Journalld=1\&queryType=Master

\title{
EFFECT OF GESAPRIM HERBICIDE WITH SOME MATERIALS ON MAIZE PLANTS
}

\author{
Sarah I.Z. Abd El-Wahab*, A.A.A. Aioub, A.E.A. El-Sobki and Rehab E.M.A. Salem \\ Plant Prot. Dept., Fac. Agric., Zagazig Univ., Egypt
}

\section{Received: 05/02/2017 ; Accepted: 12/03/2017}

\begin{abstract}
Field experiment was conducted to investigate the efficiency of pre-emergence herbicide, Gesaprim and it's mixtures with some materials on mineral contents, growth, and residual effect of Gesaprim on soil of maize plants during 2015 and 2016 growing seasons in Sharkia Governorate. Gesaprim $(\mathrm{G})$ was added at the rate of $750 \mathrm{~g} / \mathrm{fad}$., and the other materials e.g. ammonion sulphate $(\mathrm{N})$, phosphoric acid $(\mathrm{P})$, potassium sulphate $(\mathrm{K})$ and Tween-40 $(\mathrm{S})$, as a surfactant were added at the rate of $215.35,243.89,215.38 \mathrm{~g}$ and $54.84 \mathrm{~cm}^{3} /$ fad., respectively. Results revealed that the herbicide Gesaprim with mixed materials gave wide range on the vegetative growth, mineral contents and residual effects in maize plants. Results showed that, average of mineral content in maize leaves from the investigated elements [(nitrogen $(\mathrm{N})$, phosphorus $(\mathrm{P})$, potassium $(\mathrm{K})$, calcium $(\mathrm{Ca})$ and sodium $(\mathrm{Na})$ )] were as follows: $1.160,0.322,1.784,0.240$ and 0.614 for Gesaprim only; while they were $1.074,0.413,1.605,0.244$ and 0.604 for surfactant only; meanwhile, averages were $1.184,0.346$, $1.760,0.245$ and 0.616 for the treatment of Gesaprim+surfactant; meanwhile, for the treatment of Gesaprim + ammonium sulphate, they were $1.251,0.322,1.674,0.245$ and $0.594(\%)$. Also, they were $1.124,0.409,1.593,0.251$ and 0.581 for the treatment of Gesaprim + phosphoric acid. For the treatment of Gesaprim + potassium sulphate, the averages were 1.138, 0.284, 1.802, 0.260 and 0.564 while average of mineral contents were 1.151, 0.667, 1.689, 0.246 and 0.584 for the treatment of hand weeding. As for control, the averages were 1.246, 0.876, 1.700, 0.237 and 0.429. Results revealed that in vegetative growth, all the treatments of Gesaprim with materials had stimulatory effect on the fresh weight of shoots expect Gesaprim alone and Gesaprim combined with potassium sulphate. While the dry weight of shoots in case of, Gesaprim alone and Gesaprim combined with materials had stimulatory effect. The residual amounts of Gesaprim mixed with materials were 5.289, 3.478, 3.627; $4.565,3.720,0.00 ; 12.332,2.017,5.591 ; 3.578,4.085,5.611$ and $3.435,5.745,5.405$ at 5,7 and 20 days after treatments by Gesaprim, G $+\mathrm{S}, \mathrm{G}+\mathrm{N}, \mathrm{G}+\mathrm{P}$ and $\mathrm{G}+\mathrm{K}$, respectively.
\end{abstract}

Key words: Gesaprim herbicide, triazine, maize plants, minerals content, growth, residual effect.

\section{INTRODUCTION}

Nowadays, the use of herbicides in agricultural activities to control weed plants and to increase food production has become an important tool to determinant of the environment. Chlorinated triazines are herbicides widely used for selective weed control and the most commonly used herbicides in the world (Pereira and Rostad, 2003). Elemental analysis of agricultural products has been conducted due to the importance of food security as well as nutritional status (Trevizan et

\footnotetext{
* Corresponding author: Tel. : +201097375706

E-mail address: zaki_arc@yahoo.com
}

al., 2008; Lei et al., 2009). It is well known that insufficient inputs of macronutrients and micronutrients degrade the quality of the product and can also adversely affect plant growth. Thereby, reducing crop chloroplasts (Brownell and Bielig, 2009). In some cases, it can be used as a substitute for $\mathrm{K}$ which is used for cell expansion. $\mathrm{K}$ plays an important role in resistance to drought. Plants suffering from $\mathrm{K}$ decrease showed chlorosis and necrosis. $\mathrm{Ca}$ has an important role in resistance to drought. $\mathrm{Ca}$ is an important element used to deliver nutrients into the plant (Mengael et al., 2010). 
In addition, agricultural products can be contaminated by pesticides, which can adversely affect human health. Pesticides are known to be carcinogenic and toxic and the endocrine system can be disturbed by pesticides (Aubertot et al., 2011).

The uptake of nutrients and their distribution to different parts of maize plants have been found to vary primarily with the fertility of the native soil, application of chemical fertilizers, the growth stage of the plant and the environmental condition (Ologunda, 2000).

Soil plays an important role in agroecosystem and the environment but information for analysis of herbicide residues in soil can be very difficult to come by contamination of soil and agricultural products by herbicides is an increasing environmental concern (Quyang et al., 2011).

This herbicide (Gesaprim 80\% WP) commonly known as atrazine. It is selectively controls annual broad-leaved weeds and some annual grass in maize. Gesaprim is absorbed through roots and foliage, the herbicide is translocated acropetally in the xylem and accumulates in the apical meristem and leaves of plant (Robert et al., 1982). The mechanism by which this herbicide acts on plants is in inhibition of photosynthesis.

Therefore, the aim of the present work was to evaluate the efficiency of the herbicide Gesaprim at the recommended dose with some materials, on the content of mineral elements in maize leaves, the vegetative growth of maize plants (shoots and roots). The residue dynamic of Gesaprim in maize soil was also studied.

\section{MATERIALS AND METHODS}

\section{Herbicide Used}

Gesaprim $(80 \%$ WP) was used at the recommended dose according to the constructions of Ministry of Agriculture, 2014, Egypt.

Gesaprim herbicide which contain $80 \%$ of atrazine as active ingredient, was broadcasted after sowing of grains directly, over the crop rows, before the first irrigation.

\section{Plant Used}

The grains of maize (Zea mays L., CV. Single hybrid Fine Seeds 101) were obtained from Ministry of Agriculture, Giza, Egypt.

\section{Field Experiment}

This study was conducted during 2015 and 2016 growing seasons at a private farm near to Faculty of Agriculture, Zagazig University, (ElShoubak village). Mechanical and chemical properties of the soil are shown in Table 1 which analyzed at Soil Department, Faculty of Agriculture, Zagazig University.

Gesaprim (G) was broadcasted directly over the ridges after sowing of maize, before the first irrigation at the rate of $750 \mathrm{~g} / \mathrm{fad}$. Meanwhile, ammonium sulphate $(\mathrm{N})$, phosphoric acid $(\mathrm{P})$, potassium sulphate $(\mathrm{K})$ and Tween $-40(\mathrm{~S})$ as a surfactant were mixed with Gesaprim at the rate of $215.35,243.89,215.38 \mathrm{~g}$ and $54.84 \mathrm{~cm}^{3} / \mathrm{fad}$., respectively.

The experiments were set up in a complete randomize plot design with four replicates for each treatment. The area of each plot was 19.5 $\mathrm{m}^{2}$ divided into four ridges, each ridge was 6.5 $\mathrm{m}$ in length $\times 0.75 \mathrm{~m}$ in width.

Also, hand hoeing (one time) after 30 days of treatment and unweed control were practiced.

Through the growing season, samples of twelve plants were randomly taken from each plot at three limited periods 30,50 and 70 days from treatment with Gesaprim alone and Gesaprim with the abovementioned materials to study their efficacy on weight of fresh and dry shoots and roots as well as some nutrition elements content in maize leaves.

\section{Determination of Nutrition Elements in Maize Leaves}

Twelve plants were pulled randomly from each plot at the indicated periods (in days) to determine some mineral percentages of (N, P, K, $\mathrm{Ca}$ and $\mathrm{Na}$ ) in maize leaves. Leaves were dried and ground and about $0.2 \mathrm{~g}$ was digested with $3 \mathrm{ml}$ of mixture of concentrated sulfuric acid and perchloric acid $(2: 1 \mathrm{~V} / \mathrm{V})$ for 15 minutes until the digestive solution become colorless, then transferred quantitivaly to $100 \mathrm{ml}$ volumetric flask (Kiston and Mellon, 1964) and minerals were determined as follows: N, P and $\mathrm{K}$ percentages in the dry leaves were determined using method of (Evenhuis and Waard, 1980). Meanwhile, $\mathrm{Ca}$ and $\mathrm{Na}$ were determined using atomic adsorption spectroscopy (Jackson, 1967). 
Table 1. Mechanical and chemical properties of the soil under investigation

\begin{tabular}{|c|c|}
\hline$\overline{\text { Character }}$ & Value \\
\hline \multicolumn{2}{|l|}{ Physical analysis } \\
\hline Clay $(\%)$ & 37.5 \\
\hline Silt (\%) & 17.6 \\
\hline Sand $(\%)$ & 44.9 \\
\hline Textural class & Clay \\
\hline $\mathrm{CaCO}_{3}(\%)$ & 0.73 \\
\hline \multicolumn{2}{|l|}{ Chemical analysis } \\
\hline pH $(1: 2.5)$ & 7.78 \\
\hline $\mathrm{EC} \mathrm{dSm}^{-1}$ & 1.97 \\
\hline $\mathbf{N a}$ & 12.3 \\
\hline $\mathbf{K}$ & 0.91 \\
\hline Ca & 5.90 \\
\hline Mg & 2.30 \\
\hline $\mathrm{CO}_{3}$ & 0.00 \\
\hline $\mathrm{HCO}_{3}$ & 1.40 \\
\hline Cl & 6.80 \\
\hline $\mathrm{SO}_{4}$ & 13.3 \\
\hline Organic matter (\%) & 1.44 \\
\hline \multicolumn{2}{|c|}{ Available contents (mg/kg soil) } \\
\hline $\mathbf{N}$ & 98 \\
\hline $\mathbf{P}$ & 64.5 \\
\hline $\mathbf{K}$ & 166 \\
\hline
\end{tabular}

\section{Determination of Herbicide Residues in Soil}

Sampling preparation for residue analysis

Samples of soil were collected at random from treated and untreated plots after 5, 7 and 20 days post- treatment. Random samples of soil were collected from three plots of each treatment. Gesaprim residues in soil were determined chromatographically. The representative samples were subjected to extraction and clean-up procedures for digested soil.

\section{Extraction and clean-up procedures}

Residues of Gesaprim were determined using QUECHERS methodology described by Lehotay (2007) and Raczkowski et al. (2011).

\section{RESULTS AND DISCUSSION}

\section{Effect of Gesaprim and some Materials on Minerals Content in Maize Leaves}

The effects of Gesaprim alone and in combination with some materials on the percentages of some elements in maize leaves are shown in Table 2.
Results in Table 2 show that after 30 days of treatment, the differences between the all treatments (excepting surfactant treatment) and control regarding the percentages of nitrogen element were insignificant. The treatment of $(\mathrm{G}+\mathrm{K})$ recorded the highest level $(1.356 \%)$ and the lowest level was recorded in case of surfactant alone $(0.984 \%)$ while, the other treatments were occupied on intermediate position. At 50 days after application all treatments reduced the nitrogen level comparing with the control. After 70 days the highest significant in case $(1.116 \%)$ was obtained when using Gesaprim plus ammonium sulphate $(\mathrm{G}+\mathrm{N})$. On the other hand, treatment of Gesaprim plus potassium sulphate $(\mathrm{G}+\mathrm{K})$ recorded the highest significant decrease in the nitrogen percentage.

Concerning the phosphorus element (Table 2 ), it is obvious that, all treatments were significantly reduced the level of phosphorus element comparing with the control at the three dates of experiment $(30,50$ and 70 days after treatment). 
Table 2. Effect of the combination between Gesaprim, some materials and hand weeding on minerals content in leaves of maize plants after 30,50 and 70 days of treatment

\begin{tabular}{|c|c|c|c|c|c|c|c|c|c|c|c|c|c|c|c|c|c|c|c|c|}
\hline \multirow[t]{3}{*}{ Treatment } & \multicolumn{20}{|c|}{ Mineral content percentage after different intervals of treatment } \\
\hline & \multicolumn{4}{|c|}{ N (\%) } & \multicolumn{4}{|c|}{$P(\%)$} & \multicolumn{4}{|c|}{$\mathrm{K}(\%)$} & \multicolumn{4}{|c|}{$\mathrm{Ca}(\%)$} & \multicolumn{4}{|c|}{$\mathrm{Na}(\%)$} \\
\hline & 30 & 50 & 70 & Average & 30 & 50 & 70 & Average & 30 & 50 & 70 & Average & 30 & 50 & 70 & Average & 30 & 50 & 70 & Average \\
\hline Gesaprim (G) & $1.207 \mathrm{a}$ & $1.211 \mathrm{ab}$ & $1.064 \mathrm{~b}$ & $1.160 \mathrm{abc}$ & $0.370 \mathrm{e}$ & $0.380 \mathrm{ef}$ & $0.218 \mathrm{f}$ & $0.322 \mathrm{~d}$ & $1.861 \mathrm{~d}$ & $1.878 \mathrm{~d}$ & $1.614 \mathrm{a}$ & $1.784 \mathrm{a}$ & $0.216 \mathrm{e}$ & $0.222 \mathrm{e}$ & $0.284 \mathrm{a}$ & $0.240 \mathrm{c}$ & $0.647 \mathrm{~b}$ & $0.662 \mathrm{ab}$ & $0.534 \mathrm{a}$ & $0.614 \mathrm{a}$ \\
\hline Surfactant (S) & $0.984 b$ & $1.211 \mathrm{ab}$ & $1.027 \mathrm{c}$ & $1.074 \mathrm{c}$ & $0.471 \mathrm{c}$ & $0.475 \mathrm{c}$ & $0.294 d$ & $0.413 \mathrm{c}$ & $1.697 \mathrm{~g}$ & $1.710 \mathrm{~g}$ & $1.409 \mathrm{c}$ & $1.605 \mathrm{~d}$ & $0.223 \mathrm{c}$ & $0.249 \mathrm{ab}$ & $0.261 \mathrm{~d}$ & $0.244 \mathrm{c}$ & $0.657 \mathrm{a}$ & $0.668 \mathrm{a}$ & $0.487 \mathrm{~d}$ & $0.604 a b$ \\
\hline $\mathbf{G}+\mathbf{S}$ & $1.258 \mathrm{a}$ & $1.283 \mathrm{ab}$ & $1.012 \mathrm{~cd}$ & $1.184 a b c$ & $0.412 \mathrm{~d}$ & 0.416 de & $0.210 \mathrm{f}$ & $0.346 \mathrm{~d}$ & $1.942 \mathrm{~b}$ & $1.956 \mathrm{~b}$ & $1.382 \mathrm{~d}$ & $1.760 \mathrm{~b}$ & $0.230 \mathrm{~cd}$ & $0.240 \mathrm{c}$ & $0.267 \mathrm{c}$ & $0.245 \mathrm{c}$ & $0.652 \mathrm{a}$ & $0.659 \mathrm{~b}$ & $0.539 a$ & $0.616 \mathrm{a}$ \\
\hline $\mathbf{G}+\mathbf{N}$ & $1.322 \mathrm{a}$ & $1.315 \mathrm{ab}$ & $1.116 \mathrm{a}$ & $1.251 \mathrm{a}$ & $0.331 \mathrm{ef}$ & $0.337 \mathrm{fg}$ & $0.300 \mathrm{~d}$ & $0.322 \mathrm{~d}$ & $1.793 \mathrm{e}$ & $1.804 b$ & $1.427 \mathrm{~b}$ & $1.674 \mathrm{c}$ & $0.239 b$ & $0.247 b$ & $0.251 \mathrm{e}$ & $0.245 \mathrm{c}$ & $0.637 \mathrm{c}$ & $0.643 \mathrm{c}$ & $0.502 \mathrm{~b}$ & $0.594 b c$ \\
\hline $\mathbf{G}+\mathbf{P}$ & $1.197 \mathrm{a}$ & $1.202 b$ & $0.974 \mathrm{e}$ & $1.124 b c$ & $0.451 \mathrm{c}$ & $0.456 \mathrm{~cd}$ & $0.322 \mathrm{c}$ & $0.409 \mathrm{c}$ & $1.743 \mathrm{f}$ & $1.754 \mathrm{f}$ & $1.284 \mathrm{~g}$ & $1.593 \mathrm{~d}$ & $0.242 b$ & $0.249 \mathrm{ab}$ & $0.263 \mathrm{~cd}$ & $0.251 \mathrm{ab}$ & $0.621 d$ & $0.628 \mathrm{~d}$ & $0.496 \mathrm{c}$ & $0.581 \mathrm{~cd}$ \\
\hline $\mathbf{G}+\mathbf{K}$ & $1.356 \mathrm{a}$ & $1.192 b$ & $0.866 \mathrm{f}$ & $1.138 \mathrm{abc}$ & $0.293 \mathrm{f}$ & $0.297 \mathrm{~g}$ & $0.262 \mathrm{e}$ & $0.284 \mathrm{e}$ & $1.982 \mathrm{a}$ & $1.992 \mathrm{a}$ & $1.432 \mathrm{~b}$ & $1.802 \mathrm{a}$ & $0.249 \mathrm{a}$ & $0.255 \mathrm{a}$ & $0.278 \mathrm{~b}$ & $0.260 \mathrm{a}$ & $0.608 \mathrm{e}$ & $0.613 \mathrm{e}$ & $0.471 \mathrm{e}$ & $0.564 \mathrm{~d}$ \\
\hline Hand weeding & $1.229 \mathrm{a}$ & $1.231 \mathrm{ab}$ & $0.994 \mathrm{de}$ & $1.151 \mathrm{abc}$ & $0.774 b$ & $0.678 b$ & $0.550 \mathrm{~b}$ & $0.667 \mathrm{~b}$ & $1.861 \mathrm{~d}$ & $1.875 \mathrm{~d}$ & $1.331 \mathrm{e}$ & $1.689 \mathrm{c}$ & $0.233 \mathrm{c}$ & $0.243 b c$ & $0.264 \mathrm{~cd}$ & $0.246 b c$ & $0.621 d$ & $0.629 \mathrm{~d}$ & $0.502 \mathrm{~b}$ & $0.584 \mathrm{c}$ \\
\hline Control & $1.212 \mathrm{a}$ & $1.466 \mathrm{a}$ & $1.060 \mathrm{~b}$ & $1.246 \mathrm{ab}$ & $0.990 \mathrm{a}$ & $0.993 \mathrm{a}$ & $0.645 \mathrm{a}$ & $0.876 a$ & $1.893 \mathrm{c}$ & $1.904 \mathrm{c}$ & $1.305 f$ & $1.700 \mathrm{c}$ & $0.227 \mathrm{~d}$ & $0.233 \mathrm{~d}$ & $0.253 \mathrm{e}$ & $0.237 \mathrm{c}$ & $0.482 \mathrm{f}$ & $0.490 \mathrm{f}$ & $0.315 f$ & $0.429 \mathrm{e}$ \\
\hline LSD 0.05 & 0.17 & 0.25 & 0.03 & 0.12 & 0.039 & 0.049 & 0.02 & 0.024 & 0.05 & 0.01 & 0.009 & 0.06 & 0.004 & 0.006 & 0.004 & 0.012 & 0.005 & 0.007 & 0.005 & 0.018 \\
\hline
\end{tabular}

Differences between means followed by same letters in each column, statistically not significant at 0.05 level of probability. 
Regarding to potassium element, it was found that the highest significant increase of the potassium level was observed with the mixture of Gesaprim+ potassium sulphate $(\mathrm{G}+\mathrm{K})$ after 30 and 50 days of application. The respective increase percentages were $1.982 \%$ and $1.992 \%$ comparing with control (1.893 and 1.904) while after 70 days of application, Gesaprim alone recorded the highest significant increase in potassium level $(1.614 \%)$, and the lowest one was recorded in case of $(\mathrm{G}+\mathrm{P})$ treatment $(1.284 \%)$ comparing with control (1.305\%) (Table 2).

Concerning the $\mathrm{Ca}$ element, all mixtures of Gesaprim with the tested materials as well as hand weeding significantly increased the $\mathrm{Ca}$ level comparing with the control. The highest significant increase took place in case of $(\mathrm{G}+\mathrm{K})$ after 30 and 50 days of application. The corresponding values were (0.249 and $0.255 \%)$. On the other hand, the lowest significant values were recorded with the treatment of Gesaprim alone $(0.216$ and $0.222 \%)$ after 30 and 50 days, comparing with $(0.227$ and $0.233 \%)$ in the control, respectively. At 70 days after application of Gesaprim alone recorded the highest significant percentage of $\mathrm{Ca}$ element $(0.284 \%)$ comparing with $(0.253 \%)$ in the control (Table 2).

In case of $\mathrm{Na}$ (Table 2) results recorded that all treatments significantly increased $\mathrm{Na}$ level comparing with the control after 30,50 and 70 days after application. The highest levels were recorded in case of surfactant alone after 30 and 50 days as well as $(\mathrm{G}+\mathrm{S})$ after 70 days of application.

With respect to all data which were collected in the this investigation, some Researches like Bailey and White (1964) had pointed out that, these and other soil properties which can be highly or significantly correlated with the lowering of herbicide phytotoxicity can also be highly or significantly inter correlated.Corbin and Selman (1971) reported that, phytotoxicity increased as the soil $\mathrm{pH}$ increased and reached a maximum at $\mathrm{pH} 6.5$ for the weak aromatic acids e.g., (dicamba), (prometone) and amitrole. Conversely phytotoxicity increased as soil $\mathrm{pH}$ decreased and reached a maximum at $\mathrm{pH} 4.3$ for the weak aliphatic acid e.g., dalapon, the cationic herbicides diquat and paraquat and nonionic herbicide e.g. vernolate. They added that, change of one $\mathrm{pH}$ unite decreased the phytotoxicity of 2,4-D, dicamba, dalapon, prometone, amitrole, paraquat and vernolate by a factor of two to four depending on the particular herbicide and $\mathrm{pH}$ values considered. In this concern, Hayes, 1970 pointed out that, the earlier conclusion which indicated that soil organic matter could reduce the phytotoxicity of atrazine and other pre-emergent herbicides. Elbert and Dumford (1976) found that phytotoxicity of atrazine was a $\mathrm{pH}$ dependent. The half-life of metribuzine decreased with the increase of soil $\mathrm{pH}$ and its degradation by soil $\mathrm{pH}$ decreased, with atrazine and metribuzine mobility with increasing concentration and soil pH (Ladlie et al., 1976). Ashton and Grafts (1981) found that soil $\mathrm{pH}$ influenced herbicide absorption and that different herbicides responded differently to change in soil $\mathrm{pH}$. Rajkaine (2010) reported that, increasing of NPK nutrient supply inspire the uptake of other nutrients too, since the plant wants keeping the desirable of nutrients in the plant parts.

\section{Effect of Gesaprim Alone and its Mixtures with Some Materials on the Growth of Maize Plants}

Results in Table 3 show the fresh and dry weights of shoots at 30,50 and 70 days. At 30 days, the treatment of $(\mathrm{G}+\mathrm{S})$ and $(\mathrm{G}+\mathrm{P})$ exhibited high values than the control, meanwhile Gesaprim only did not exceed than that of control. The materials of surfactant or potassium sulphate had stimulatory effect on the action of Gesaprim herbicide.

After 50 days, Gesaprim and Gesaprim with all materials had a stimulatory effect on the fresh shoots weight of maize plants. The highest value was recorded with treatment of Gesaprim with phosphoric acid followed by Gesaprim with surfactant Tween -40, while Gesaprim alone was higher in its value than Gesaprim combined with ammonium sulphate.

After 70 days, the treatment of Gesaprim alone, Gesaprim with surfactant, Gesaprim with ammonium sulphate had a stimulatory effect on the fresh shoot weights of maize plants. 
Abd El-Wahab, et al.

Table 3. Average of fresh and dry shoot weight (in gram) of treated maize plants after different periods (in days) of treatment

\begin{tabular}{lccccc}
\hline Treatment & \multicolumn{5}{c}{ The fresh weight of the plant shoots at the indicated periods } \\
\cline { 2 - 6 } & $\mathbf{3 0}$ & $\mathbf{5 0}$ & $\mathbf{7 0}$ & Average $^{*}$ & Response $^{* * *}$ \\
\hline Gesaprim & 159.16 & 215.53 & 642.49 & 339.06 & $(-)$ \\
Surfactant & 94.29 & 132.12 & 316.01 & 180.80 & $(-)$ \\
G+S & 250.46 & 275.81 & 774.20 & 433.49 & $(+)$ \\
G+N & 144.17 & 207.15 & 745.98 & 365.76 & $(+)$ \\
G+P & 275.16 & 326.91 & 459.39 & 353.82 & $(+)$ \\
G+K & 174.99 & 127.02 & 638.93 & 313.64 & $(-)$ \\
Hand weeding & 203.25 & 162.03 & 679.03 & 348.10 & \\
Control & 203.25 & 162.03 & 679.03 & 348.10 & \\
& The dry weight of the plant shoots at the indicated periods & \\
Gesaprim & 24.39 & 55.68 & 211.93 & 97.33 & $(+)$ \\
Surfactant & 24.13 & 28.41 & 69.93 & 40.82 & $(-)$ \\
G+S & 58.77 & 61.16 & 110.35 & 76.76 & $(+)$ \\
G+N & 27.97 & 48.27 & 127.60 & 67.94 & $(+)$ \\
G+P & 66.53 & 63.79 & 163.31 & 97.87 & $(+)$ \\
G+K & 32.07 & 47.80 & 60.81 & 46.89 & $(+)$ \\
Hand weeding & 43.16 & 36.90 & 52.25 & 44.10 & \\
Control & 43.16 & 36.90 & 52.25 & 44.10 & \\
\hline * Averag & & $* *$ &
\end{tabular}

* Average of three replicates.

** $(+)$ increase in weight, comparing with control treatment.

(-) decrease in weight, comparing with control treatment.

For the fresh weight of maize shoots the treatment of $(\mathrm{G}+\mathrm{S}),(\mathrm{G}+\mathrm{N})$ and $(\mathrm{G}+\mathrm{P})$ exhibited an increase in fresh weight, while the treatment of Gesaprim alone and $(\mathrm{G}+\mathrm{K})$ exhibited a decrease in fresh weight.

For dry weight of maize shoots, results in the same Table revealed that, all treatments of Gesaprim with the tested materials exhibited positive sign, indicating presence of increasing in dry weight during the whole age of plants with the exception of that surfactant alone.

Results in Table 4 highlighted on the fresh and dry weight of roots in maize at three fixed times 30, 50 and 70 days.

At 30 days, results reveled that, $(\mathrm{G}+\mathrm{S})$ and $(\mathrm{G}+\mathrm{P})$ were stimulated than other treatments like $(\mathrm{G}+\mathrm{N})$ or $(\mathrm{G}+\mathrm{K})$ which recorded the highest value $(15.67 \mathrm{~g})$ and $(24.83 \mathrm{~g})$, while $(\mathrm{G}+\mathrm{N})$ recorded $(9.87 \mathrm{~g})$ and $(\mathrm{G}+\mathrm{K})$ recorded $(26.39 \mathrm{~g})$, each other was less than control, which exhibited (15.76 g).
At 50 days, we can follow the development of root and effect of treatment on its weight, to find out that, the treatments of $(\mathrm{G}+\mathrm{S}),(\mathrm{G}+\mathrm{N})$, $(\mathrm{G}+\mathrm{P})$ and Gesaprim alone were superior in their effect on fresh weight of roots.

Compared to the control and hand weeding, results indicated the presence of stimulatory effect for Gesaprim and its mixtures with the tested materials except potassium sulphate with Gesaprim which recorded the lowest value compared to control.

At 70 days, results revealed that, only two treatments i.e. $(\mathrm{G}+\mathrm{S})$ and $(\mathrm{G}+\mathrm{N})$ had stimulatory effect on the fresh weight of maize roots, while the other treatments e.g., Gesaprim alone and Gesaprim with potassium sulphate had a moderate effect, while the treatment of surfactant alone had the lowest effect.

To clear the stimulatory effect of treatments, we found that there were positive responses for the treatments of $(\mathrm{G}+\mathrm{K})$ and $(\mathrm{G}+\mathrm{P})$ while the other treatments had negative responses. 
Table 4. Average of fresh and dry roots weight (in gram) of treated maize plants after different periods (in days) of treatment

\begin{tabular}{lccccc}
\hline Treatment & \multicolumn{5}{c}{ The fresh weight of plant roots at the indicated periods } \\
\cline { 2 - 6 } & $\mathbf{3 0}$ & $\mathbf{5 0}$ & $\mathbf{7 0}$ & Average* $^{*}$ & Response** $^{* *}$ \\
\hline Gesaprim & 18.17 & 17.87 & 62.97 & 33.00 & $(-)$ \\
Surfactant & 15.43 & 19.32 & 29.21 & 21.32 & $(-)$ \\
G+S & 15.67 & 22.13 & 77.01 & 38.27 & $(-)$ \\
G+N & 9.87 & 16.19 & 74.48 & 33.51 & $(-)$ \\
G+P & 24.83 & 41.32 & 86.33 & 50.82 & $(+)$ \\
G+K & 26.39 & 28.43 & 157.63 & 70.81 & $(+)$ \\
Hand weeding & 15.76 & 27.58 & 89.41 & 44.25 & \\
Control & 15.76 & 27.58 & 89.41 & 44.25 &
\end{tabular}

\begin{tabular}{|c|c|c|c|c|c|}
\hline \multicolumn{6}{|c|}{ The dry weight of plant roots at the indicated periods } \\
\hline Gesaprim & 3.39 & 6.01 & 39.32 & 16.24 & $(+)$ \\
\hline Surfactant & 6.21 & 8.88 & 15.03 & 10.04 & $(-)$ \\
\hline $\mathbf{G}+\mathbf{S}$ & 4.87 & 7.77 & 32.39 & 15.01 & $(-)$ \\
\hline $\mathbf{G}+\mathbf{N}$ & 2.28 & 7.32 & 38.22 & 15.94 & $(+)$ \\
\hline $\mathbf{G}+\mathbf{P}$ & 7.67 & 12.97 & 49.51 & 23.38 & $(+)$ \\
\hline $\mathbf{G}+\mathbf{K}$ & 4.29 & 12.22 & 27.67 & 14.72 & $(-)$ \\
\hline Hand weeding & 5.66 & 13.06 & 27.82 & 15.51 & \\
\hline Control & 5.66 & 13.06 & 27.82 & 15.51 & \\
\hline
\end{tabular}

(-) decrease in weight comparing with control treatment.

For the dry weight of roots which were represented in Table 4. As for 30 days, results demonstrated that, the superior effect of treatments was a share for the $(\mathrm{G}+\mathrm{P})$ which recorded the highest value ( $7.67 \mathrm{~g})$ followed by surfactant $(6.21 \mathrm{~g})$.

For the 50 days, it was found that the highest value was recorded by the treatment of $(\mathrm{G}+\mathrm{P})$ that indicated $(12.97 \mathrm{~g})$ although it was less than control which exhibited (13.06 g).

For the 70 days, results in Table 4 declare that, the best combination of Gesaprim and its mixtures with the tested materials was Gesaprim and potassium sulphate which recorded (27.67 g) followed by the treatment of Gesaprim alone which recorded (39.32 g) while the lowest value was recorded by the treatment of surfactant alone recording $(15.03 \mathrm{~g})$.

It is worth to mention that, the treatment of $(\mathrm{G}+\mathrm{K})$ was equal to hand weeding and control representing by $(27.82 \mathrm{~g})$.
For determination response of treatments on weight of root, we can observe the positive response to the treatment of Gesaprim, Gesaprim + ammonium sulphate and Gesaprim + phosphoric acid which led to increase in dry weight of roots after the indicated periods. These findings were found to be in harmony with those recorded by (Hussein, 1996; Erzsebet et al., 2007).

\section{Residues of Gesaprim and its Mixture in Soil of Maize Field}

Results shown in Table 5 and Fig. 1 clear that, after 5 days of treatment, residues of Gesaprim, Gesaprim $+\mathrm{S}$, Gesaprim $+\mathrm{N}$, Gesaprim $+\mathrm{P}$ and Gesaprim $+\mathrm{K}$ in maize soil were $5.289,4.565,12.332,3.578$ and $3.435 \mathrm{mg} /$ $\mathrm{kg}$. These amounts were $3.478,3.720,2.017$, 4.085 and $5.745 \mathrm{mg} / \mathrm{kg}$ after 7 days of treatment. Also, these amounts were $3.627,0.00,5.591$, 5.611 and $5.405 \mathrm{mg} / \mathrm{kg}$ after 20 days of treatment, respectively.

These results are in harmony with those obtained by (Howard, 1999; Shobha, 2014; 
Table 5. Residues $(\mathrm{mg} / \mathrm{kg})$ of Gesaprim in the soil of maize field

\begin{tabular}{cccccc}
\hline Days after treatment & Gesaprim & Gesaprim+S & Gesaprim+N & Gesaprim+P & Gesaprim+K \\
\hline $\mathbf{5}$ & 5.289 & 4.565 & 12.332 & 3.578 & 3.435 \\
$\mathbf{7}$ & 3.478 & 3.720 & 2.017 & 4.085 & 5.745 \\
$\mathbf{2 0}$ & 3.627 & 0.00 & 5.591 & 5.611 & 5.405 \\
\hline
\end{tabular}

* Based on the actual remainder of the residues.

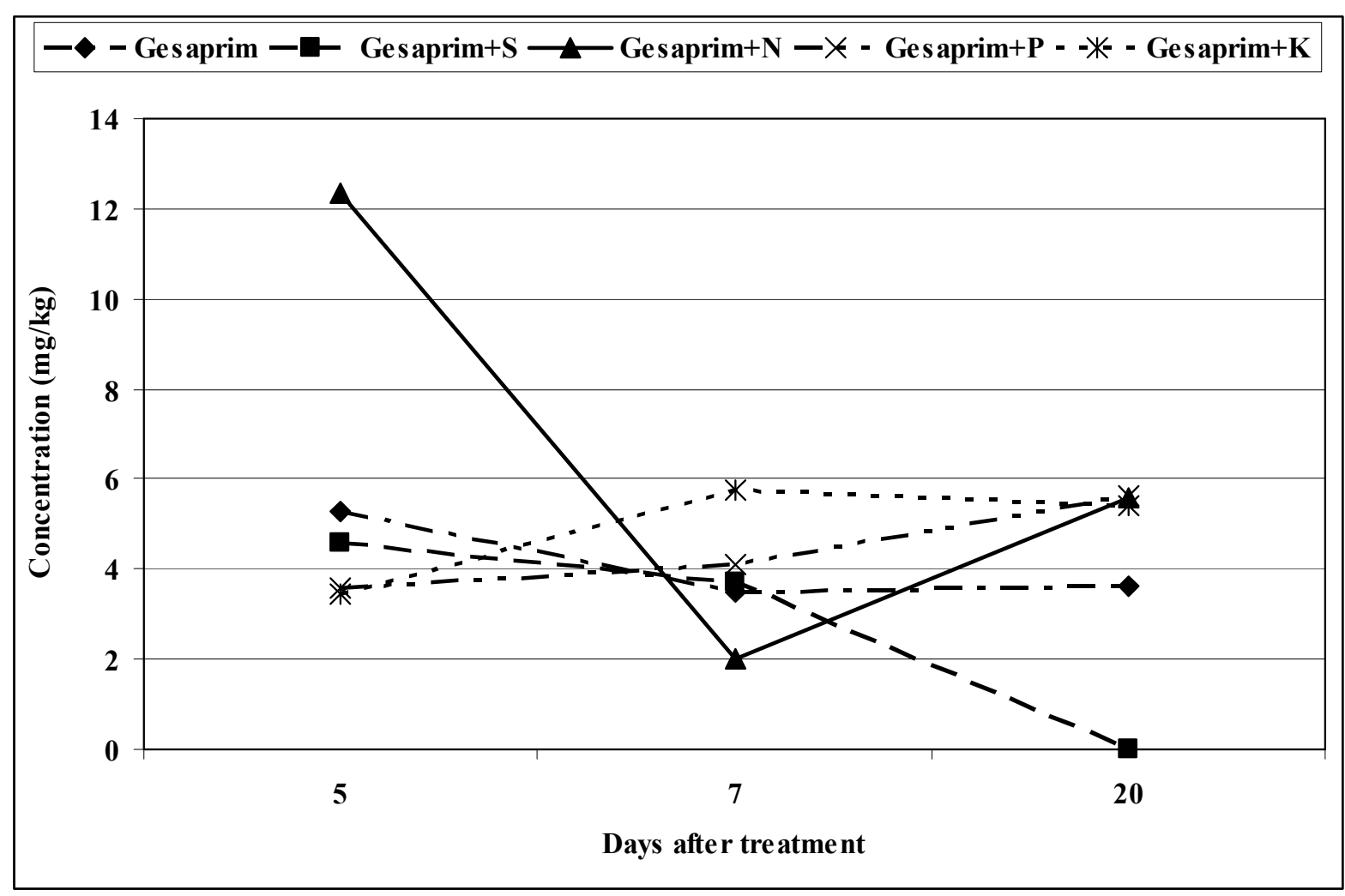

Fig. 1. Residues (mg/kg) of Gesaprim in the soil of maize field

Xiaoxiao et al., 2016). Herbicide residues in crop produce above the safe level can cause health hazards to men and animals. Fate of herbicide in soil depends on number of processes such as volatilization, leaching, runoff and degradation by microbes, chemical processes and photodecomposition. Meanwhile, Appleby (1985) indicated that organic matter can be a major reason for a wide variation in plant response to seven herbicides concentration in the soil. Also, Mayer (1987) reported that, some herbicides may be available to plants as a vapor in the phase of the soil, but most must be present in the soil solution before they can be absorbed by the germinating weed seedling.
Nasseri (2009) reported that, atrazine leaching and dissipation rate in different soil profiles in the four sampling regions were high and significant. Therefore, there is a high risk of atrazine pollution in groundwater resources of the region.

\section{REFERENCES}

Appleby, A.P. (1985). Factor in examining fate of herbicides in soil bioassay. Weed Sci., 35: 567-582.

Ashton, F.M. and A.F. Grafts (1981). Mode of Action of Herbicides. $2^{\text {nd }}$ Ed., John Wily and Sons, New York, 525. 
Aubertot, J.N., J.M. Barbier, A. Carpentier, J.J. Gril, L. Guichard and P. Lucas (2011). Pesticides agriculture and the environment reducing the use of pesticides and limiting their environmental impact. Collect. Sci. Expert Rep.

Bailey, G.W. and J.L. White (1964). Review of adsorption and desorption of organic pesticides by soil colloids, with implications concerning pesticide bioactivity. J. Agr. Food Chem., 12: 324.

Brownell, P.P. and L.M. Bielig. (2009). The role of sodium in the conversion of pyruvate to phosphoenolpyruvate in mesophyll chloroplasts of C14 plants. Aust. J. Plant Physiol., 23 (2): $171-177$.

Corbin F.T. and F.L. Selman (1971). Influence of $\mathrm{pH}$ on the phytotoxicity of herbicides in soil. Weed Sci. Soc. Ame., 19 (3): 233-239.

Elbert, E. and S.W. Dumford (1976). Effect of atrazine herbicide on the physiology of plant. Residue Rev., 65: 100-103.

Erzsebet, N., G. Kazinczi and M. Nadasy (2007). Relationship between herbicide application and mineral nutrition of sunflower. Zbornik Predavanj in Referatov and Slovenskega Posvetovanja o Varstvu Rastlin., 304 - 308.

Evenhuis, B. and P.W. Waard (1980). Principle and practies in plant analysis FAO Soils Bell., 38 (1): 152-163

Hayes, M.H.B. (1970). Adsorption of atrazine herbicides on soil organic matter, including a short review on soil organic matter chemistry. Weed Sci., 32 : 131-174.

Howard, M.D. (1999). Pesticide Adsorption and Half-life. SCS/ARS/CES. Pesticide Properties Database for Environmental Decision.

Hussein, F.H. (1996). Interactive effects of nitrogen sources and weed control on growth and nutrient uptake of weeds and grain yield of maize (Zea mays L.); Mansoura J. Agric. Sci., Mansoura Univ., 21: 10 - 22.

Jackson, M.L. (1967). Soil Chemical Analysis. Prentice Hall Inc. Englewood cliffs NJ Library of Cong., USA.
Kiston, R.E. and M.G. Mellon (1964). Colorimetric determination of phosphorus as moly divan adosphoric acid. Ind. Eng. Chem. Anal. Ed., 16: 379 - 383.

Ladlie. J.S., W.F. Megitt and D. Penner (1976). The role of $\mathrm{pH}$ on metribuzin dissipation in field soil. Weed Sci., 24: 508 - 515.

Lehotay, S.L. (2007). Determination of pesticide residues in foods by acetonitrile extraction and partitioning with magnesium sulfate, collaborative study. J. AOAC Int., 90 (2): $485-520$.

Lei, W., V. Motta-Ros, M. Boueri, H. Zeng (2009). Time-resolved characterization of laser induced plasma from fresh potatoes. Spectrochim. Acta. Part B: At Spectrosc, 64 (9): 891 - 898.

Mayer, J.R. (1987). Effect of soil moisture in the efficacy and selectivity of soil-applied herbicides. Rev. Weed Sci., 3: 19-20.

Mengael, K., E.A. Kirkby, H. Kosegarten and T. Apple (2010). Principles of Plant Nutrition. Kluwer Academic Publishing: Dordrecht the Netherlands, 849.

Nasseri, S. (2009). Fate of atrazine in the agricultural soil of corn fields in Fars province of Iran. Iran J. Environ. Health. Sci. Eng., 6 (4): 223-232.

Ologunda, O.O. (2000). Effect of nitrogen and population on yield and yield component of maize (Zea mays L.). M.Sc. Thesis, Graduate School. Univ., Missouri, Columbia, 164.

Pereira, W.E. and C.E. Rostad (2003). Occurrence distribution and transport of herbicides and their degradation products in the lower Mississippi River and its Tributary. Environ. Sci. Technol., 24: 1400 - 1406.

Quyang, Y., R.S. Mansell and P.N. Kedi-Kizza, (2011). A simple high performance liquid chromatography method for analyzed paraquat in soil solution samples. J. Environ. Qual., (33): 406 - 408.

Raczkowski, M., A. Holodynska, A. Nowacka and B. Gnusowski (2011). Application of the QUECHERS method for determination of pesticide residues in tomato samples using GC-NPD / ECD. Progress in Plant, 51 (2): $727-731$. 
Rajkaine, V.K. (2010). A tapanyaghiany hatasa a tapanyagfelvetelre in Fuleky gy. (szerk). Tapanyag -gazdalkodas. Mezogazda Kiado, Budapest: 128- 130.

Robert, A.J., C.K. Wood and W.W. Fletcher (1982). The absorption, Herbicides and Plant Growth Regulators. Published by w.w. Fletcher and R.C. and Translocation of SoilApplied Herbicides, Kirkwood, Granada, London, Toronto, Sydney, and New York, 147-177.

Shobha, S. (2014). Herbicides residues in soil, water, plants and non-targeted organisms, human health implications an Indian perspective. Indian J. Weed Sci., 46 (1): 66 - 85.

Trevizan, L.C.; D.Jr. Santo, R.E. Samad, N.D. Vieira, N.D. Nomura and L.C. Rufini (2008). Evaluation of laser induced breakdown spectroscopy for the determination of the macronutrients in plant materials. Spectrochim Acta, Part B, Atomic Spectroscopy, 63 (10): 1151 - 1158.

Xiaoxiao, F., J. Yu., L. Pan, G. Song and H. Zhang (2016). Dissipation and residues of dichlorop-p and bentazone in wheat-field ecosystem. Int. J. Environ. Res. and Public. Health, 45 (1): 2 - 14.

\section{تأثثير مبيد الحشائش جيسابريم مع بعض المواد على نباتات الذرة الشامية

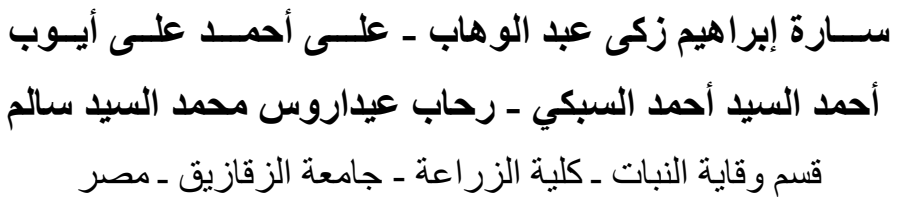

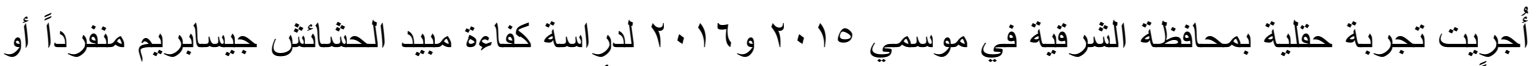

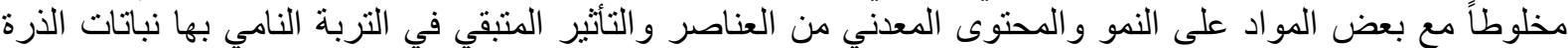

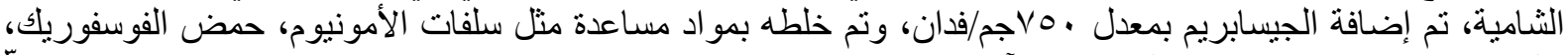

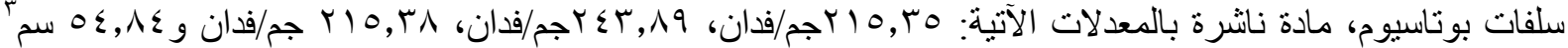

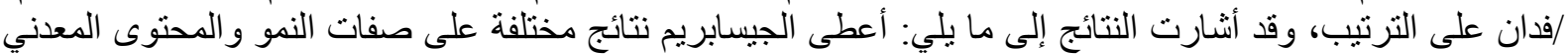

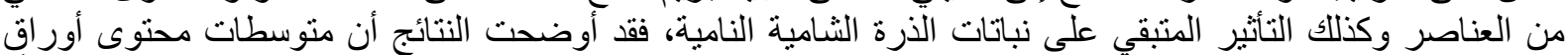

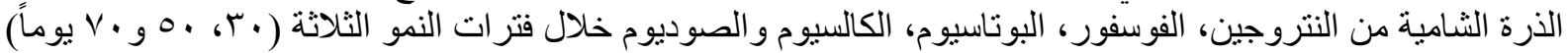

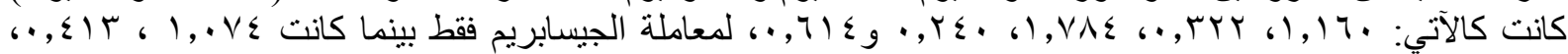

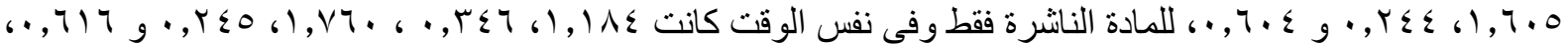

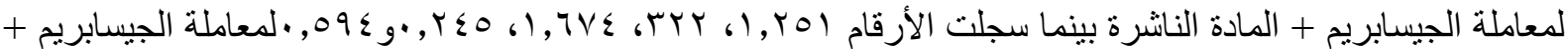

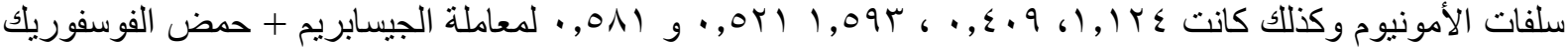

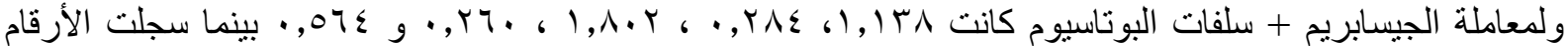

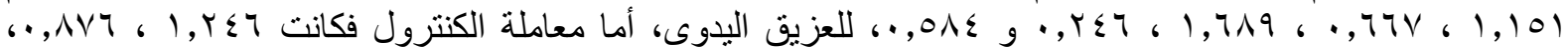

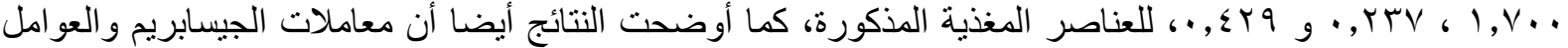

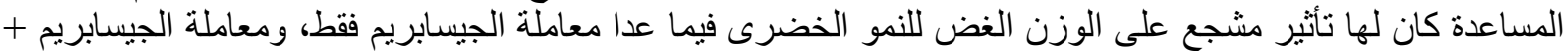

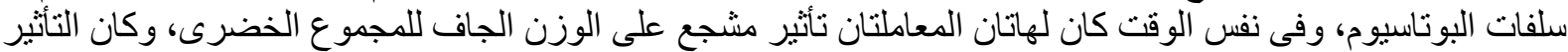

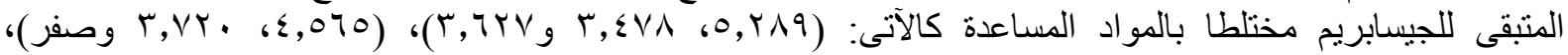
V،

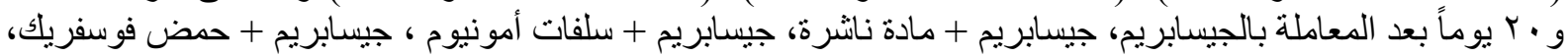

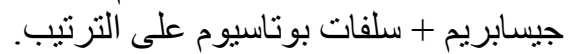

